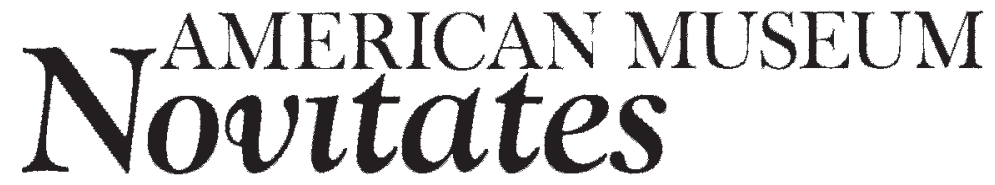

PUBLISHED BY THE AMERICAN MUSEUM OF NATURAL HISTORY CENTRAL PARK WEST AT 79TH STREET, NEW YORK, NY 10024 Number 3577, 21 pp., 15 figures

June 28, 2007

\title{
First Records of Extant Hispaniolan Spiders of the Families Mysmenidae, Symphytognathidae, and Ochyroceratidae (Araneae), Including a New Species of Ochyrocera
}

\author{
GUSTAVO HORMIGA, ${ }^{1}$ FERNANDO ALVAREZ-PADILLA, ${ }^{2}$ AND \\ SURESH P. BENJAMIN ${ }^{3}$
}

\begin{abstract}
A new species of ochyroceratid spider, Ochyrocera cachote, n.sp., is described and its unique web architecture is documented. This is the first record of Ochyroceratidae for the extant fauna of Hispaniola. Additional new family records include Symphytognathidae (Patu sp. and Symphytognatha sp.) and Mysmenidae (Microdipoena sp.), with the latter family having been previously recorded from the fossil amber fauna. This makes a new total of 46 spider families recorded from the extant Hispaniolan fauna, but on the whole the island's araneofauna remains poorly known and warrants further investigation.
\end{abstract}

\section{INTRODUCTION}

The taxonomic knowledge of the spider fauna of the Dominican Republic is unique because more families are known from fossils in Miocene amber than are recorded from extant species (Penney, 1999; Penney and Pérez-Gelabert, 2002). It is also the region of the world where the fossil fauna is most similar to that of the Recent fauna. The spiders of the Dominican Republic preserved in amber are relatively well known (Penney, 2006). The Dominican amber and the extant fauna are ecologically comparable because the amber was formed in a tropical climate similar to that in the region at the present time

\footnotetext{
${ }^{1}$ Department of Biological Sciences, The George Washington University, Washington, DC 20052; Research Associate, Department of Invertebrates, American Museum of Natural History (hormiga@gwu.edu).

${ }^{2}$ Department of Biological Sciences, The George Washington University, Washington, DC 20052 (fap@gwu.edu).

${ }^{3}$ Department of Biological Sciences, The George Washington University, Washington, DC 20052 (sureshb@gwu.edu).
} 
(Penney and Pérez-Gelabert, 2002). However, apart from the pioneering works by Elizabeth Bryant (1943, 1945, 1948), the extant spider fauna of Hispaniola has not been studied in much detail (for a history of Hispaniolan araneology, see Penney and Pérez-Gelabert, 2002). During the course of a recent field trip to the Dominican Republic we had the opportunity to collect and study spiders in four areas with different habitats and elevations. In this paper we report on three spider families that were previously undiscovered for the extant fauna of Hispaniola: Ochyroceratidae, Mysmenidae, and Symphytognathidae. The ochyroceratid species is morphologically very similar to one of the species described from amber, and it is formally described here.

Ochyroceratidae is a relatively small family (146 described species in 13 genera) of small ecribellate haplogyne spiders with a cosmotropical distribution (Platnick, 2006). Although the natural history of ochyroceratids is not well known (Machado, 1951; DeelemanReinhold, 1995), it seems that many of them build sheet webs, sometimes with conspicuous parallel silk lines in the sheet (figs. 13B, 14D). Recently, Wunderlich (1988, 2004a) described two fossil species of Ochyroceratidae from the Dominican Republic (Arachnolithulus pygmaeus Wunderlich, 1988 and A. longipes Wunderlich, 2004). To accommodate the first of these two Dominican fossil species he erected the genus Arachnolithulus Wunderlich, 1988. However, Wunderlich was uncertain as to relationships of Arachnolithulus, pointing out the need for more specimens, fossil and extant. Penney (1999) predicted extant Hispaniolan ochyroceratids (and mysmenids) based on their occurrence in the amber fauna. Alayón-García (2001) reported the presence of ochyroceratids from Navassa, a $5.2-\mathrm{km}^{2}$ island $64 \mathrm{~km}$ west of Hispaniola. During our fieldwork in the Dominican Republic we found a new species of Ochyroceratidae in leaf litter, in a patch of cloud forest near Paraíso (Barahona Province). This new species is morphologically similar to the extinct Dominican species Arachnolithulus longipes (known after a single male specimen in amber) and to the extant Ochyrocera thibauldi Emerit and Lopez, 1985 from the
Lesser Antilles (Dominica and Guadaloupe). In this paper we describe the new species in detail and document its web architecture. Additionally, we report the presence of extant species from the araneoid families Mysmenidae and Symphytognathidae in the island for the first time. Two fossil species of Mysmenidae, Mysmenopsis lissycoleyae Penney, 2000 and Dominicanopsis grimaldii Wunderlich, 2004, have been described from Dominican amber (Penney, 2000; Wunderlich, 2004b). The family Symphytognathidae had not been recorded before. Schawaller's (1981) records of eight symphytognathid specimens in Dominican amber held at the Staatliches Museum fur Naturkunde (Stuttgart, Germany) are misidentifications of theridiids (Wunderlich, 2004c: 228).

\section{MATERIALS AND METHODS}

Taxonomic descriptions follow the format of Hormiga (1994, 2002). Specimens of fossil Ochyroceratidae in Dominican amber were not examined. Discussion of their relationships is based on the published text and figures. Specimens were examined and illustrated using a Leica MZ 16A stereoscopic microscope with a camera lucida. Further details were studied using a Leica DMRM compound microscope with a drawing tube. Some microscopic images were recorded using a Nikon DXM1200F digital camera and stacked using the software package AutoMontage. A LEO 1430VP scanning electron microscope was also used to study and photograph morphological features. Left structures (e.g., palps, legs) are depicted unless otherwise stated. Hairs and macrosetae are usually not depicted in the final drawings. All morphological measurements are given in millimeters. Somatic morphology measurements were taken using a scale reticle in the dissecting microscope. Eye diameters are taken from the span of the lens. Cephalothorax length and height were measured in lateral view, and its width was taken at the widest point. Similarly, the length and height of the abdomen were measured in lateral view, and the width was taken as the widest point as seen from a dorsal view. Measurements of the abdomen are only approximations because the 
abdomen size changes more easily in preserved specimens than do other more sclerotized parts (e.g., the chelicerae). Total length was measured in lateral view and is also an approximation because it involves the size of the abdomen and its relative position. Approximate femur lengths were measured in lateral view, without detaching the legs from the animal, by positioning the article being measured perpendicularly. Female genitalia were excised using surgical blades or sharpened needles. Epigyna and palps were transferred to methyl salicylate (Holm, 1979) for examination under the microscope, temporarily mounted as described in Grandjean (1949) and Coddington (1983). Male palps examined with the SEM were first excised and transferred to a vial with $70 \%$ ethanol and then cleaned ultrasonically for 1-3 minutes. The specimen was then transferred to absolute ethanol and left overnight. After critical point drying, the specimens were glued to rounded aluminum rivets using an acetone solution of Acryloid B-72 and coated with gold-palladium for examination with the SEM. For SEM examination of the tracheal system, the nonchitinous abdominal tissue was digested with SIGMA Pancreatin LP 1750 enzyme complex (Alvarez-Padilla and Hormiga, in press) in a solution of sodium borate prepared following the concentrations described in Dingerkus and Uhler (1977).

Webs were photographed after dusting them with cornstarch (Eberhard, 1976) and photographed with a Nikon F100 using a 60$\mathrm{mm}$ macro lens and a speedlight. All photographs have associated voucher specimens.

\section{Anatomical Abbreviations}

$\begin{array}{ll}\text { Male Palp } & \\ \mathrm{E} & \text { embolus } \\ \mathrm{m} 30 & \text { claw extensor muscle } \\ \mathrm{T} & \text { tegulum } \\ \mathrm{tm} 29 & \text { tendon of claw flexor mus } \\ \text { Female } & \text { Genitalia } \\ \mathrm{S} & \text { spermatheca } \\ \text { Somatic } & \text { Morphology } \\ \mathrm{AC} & \text { aciniform gland spigot(s) } \\ \text { ALE } & \text { anterior lateral eye(s) } \\ \text { ALS } & \text { anterior lateral spinneret } \\ \text { AME } & \text { anterior median eye(s) } \\ \text { ATS } & \text { anterior tracheal spiracle }\end{array}$

$\begin{array}{ll}\text { MAP } & \text { major ampullate gland spigot(s) } \\ \text { mAP } & \text { minor ampullate gland spigot(s) } \\ \text { PI } & \text { piriform gland spigot(s) } \\ \text { PLS } & \text { posterior lateral spinneret } \\ \text { PMS } & \text { posterior median spinneret } \\ \text { PTS } & \text { posterior tracheal spiracle }\end{array}$

\section{TAXONOMY}

OCHYROCERATIDAE FAGE, 1912
OCHYROCERA SIMON, 1891

Type Species: Ochyrocera arietina Simon, 1891 by original designation.

Composition: In addition to $O$. cachote, n.sp., the genus Ochyrocera includes 21 species (Platnick 2006), most of them from the Neotropical region. There are also species described from Cuba, the Lesser Antilles, including the type species, and Samoa.

\section{Ochyrocera cachote, new species}

figures $1-12$

TYPE: Male holotype and female paratype from Barahona Province, Paraíso, Reserva Natural Cachote, cloud forest surrounded by secondary growth, N $18^{\circ} 05^{\prime} 54.8^{\prime \prime}$ : W $71^{\circ} 11^{\prime} 22.0^{\prime \prime}, 1220 \mathrm{~m}, 6-9 . I V .2005$, G. Hormiga, F. Alvarez-Padilla, and S.P. Benjamin (deposited in MCZ).

ETYMology: The species epithet is a noun in apposition taken from the type locality.

Diagnosis: Males of Ochyrocera cachote, n.sp. can be distinguished from other species of Ochyrocera by the absence of a clypeal apophysis (fig. 1B) and the details of the cheliceral teeth (fig. 2C, D), including the presence of a large tooth toward the base of the cheliceral furrow. The cymbial apophysis and the embolus shape (figs. 2A, B, 8A-C) are also diagnostic. The lack of a monographic treatment of Ochyrocera and the absence of detailed and uniform descriptions of the species currently placed in the genus make it impossible to accurately diagnose females. Most likely the shape of the spermathecae (fig. 3B) combined with the cheliceral teeth (fig. $3 \mathrm{C}, \mathrm{D}$ ) are unique for this species.

DesCRIPTION: Male (holotype): Total length 2.83. Cephalothorax 1.09 long, 0.89 wide, 0.31 high. Sternum 0.59 long, 0.61 wide. 


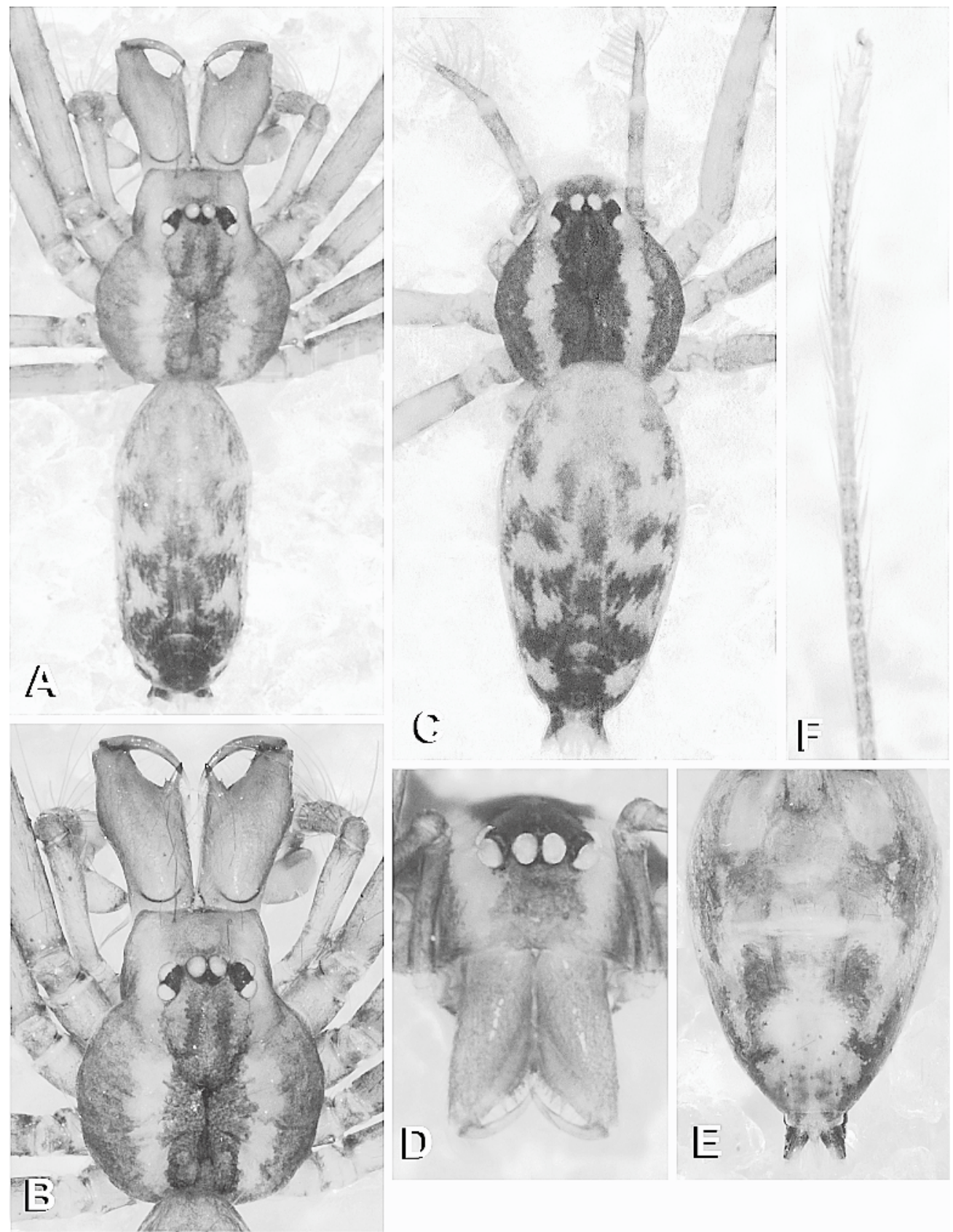

Fig. 1. Ochyrocera cachote, n.sp. A, Male, dorsal. B, Male prosoma, dorsal. C, Female, dorsal. D, Female prosoma, anterior. E, Female abdomen, ventral. F, Male, left leg I, mesal.

Abdomen 1.74 long, 0.6 wide, 0.65 high. Specimens in alcohol have general bluish appearance. Cephalothorax bluish yellow with two light longitudinal bands running in parallel from clypeus through posterior carapace margin (fig. 1A, B). Chelicerae yellowish, fangs red brown. Six eyes in three groups; eyes slightly elevated, with black rings. AME 


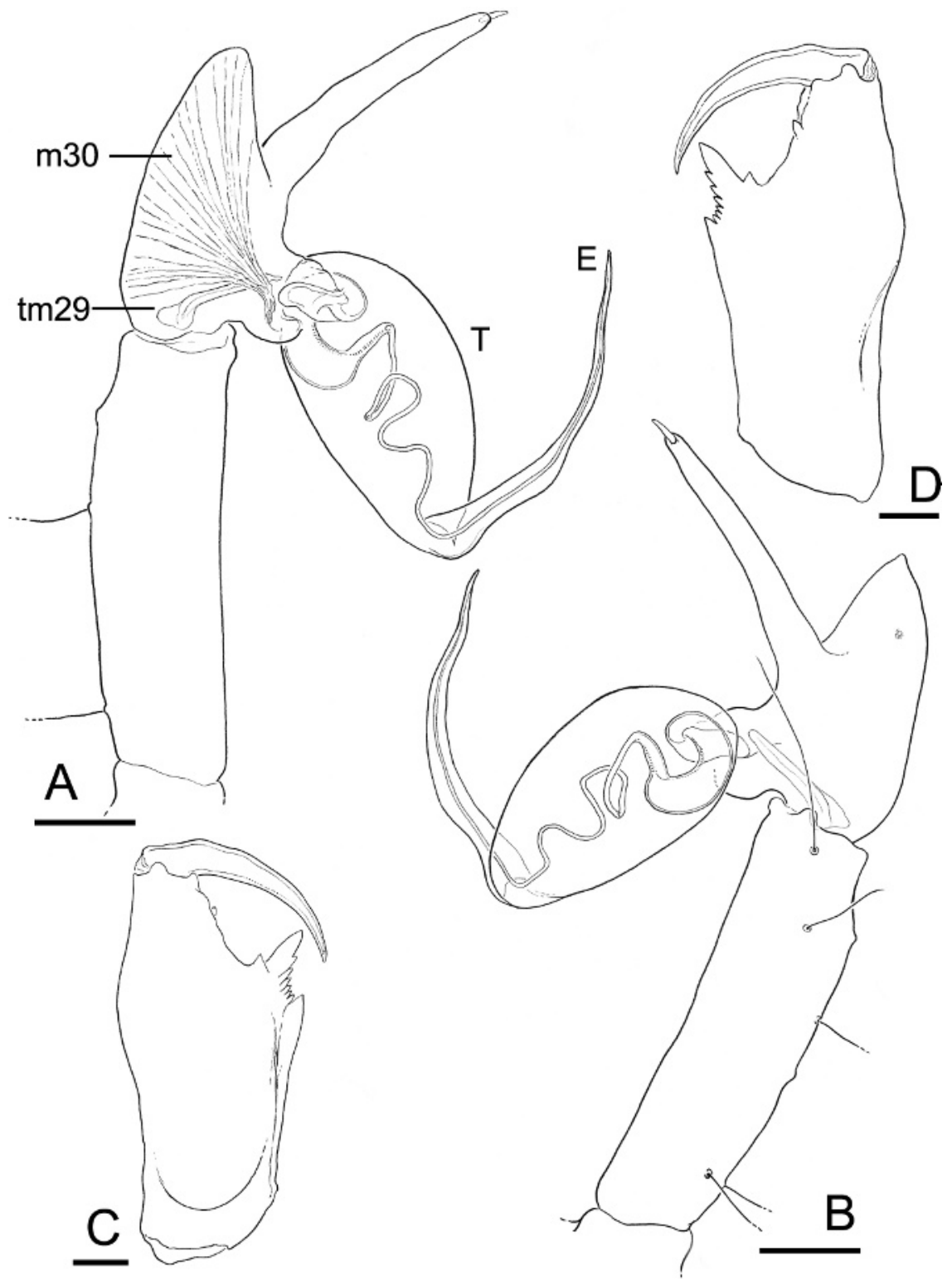

Fig. 2. Ochyrocera cachote, n.sp., male. A, Palp, mesal. B, Palp, ectal. C, Chelicera, dorsal. D, Chelicera, ventral. Scale bars $0.1 \mathrm{~mm}$.

diameter $0.09,0.3$ times one AME diameter away from ALE. Clypeus height 0.29 , projecting forward, with two pairs of setae, with ectal pair longer and more robust than distal pair (fig. 4A, C, E). Sternum yellowish with dark lateral margin, seven macrosetae in three rows of 3,2, 2 setae each; ectal setae longer and more robust than distal setae. Endites with several macrosetae. Labial anterior margin notched (fig. 4F). Legs yellowish with black blotches, no apparent pattern; tarsi with cuticular folds and pigmentation pattern (fig. 1F) that gives appearance of pseudosegmentation. Leg formula 1432. Femur I 4.03 long, 3.7 times length of cephalothorax. Chelicerae anteriorly protruding with promi- 


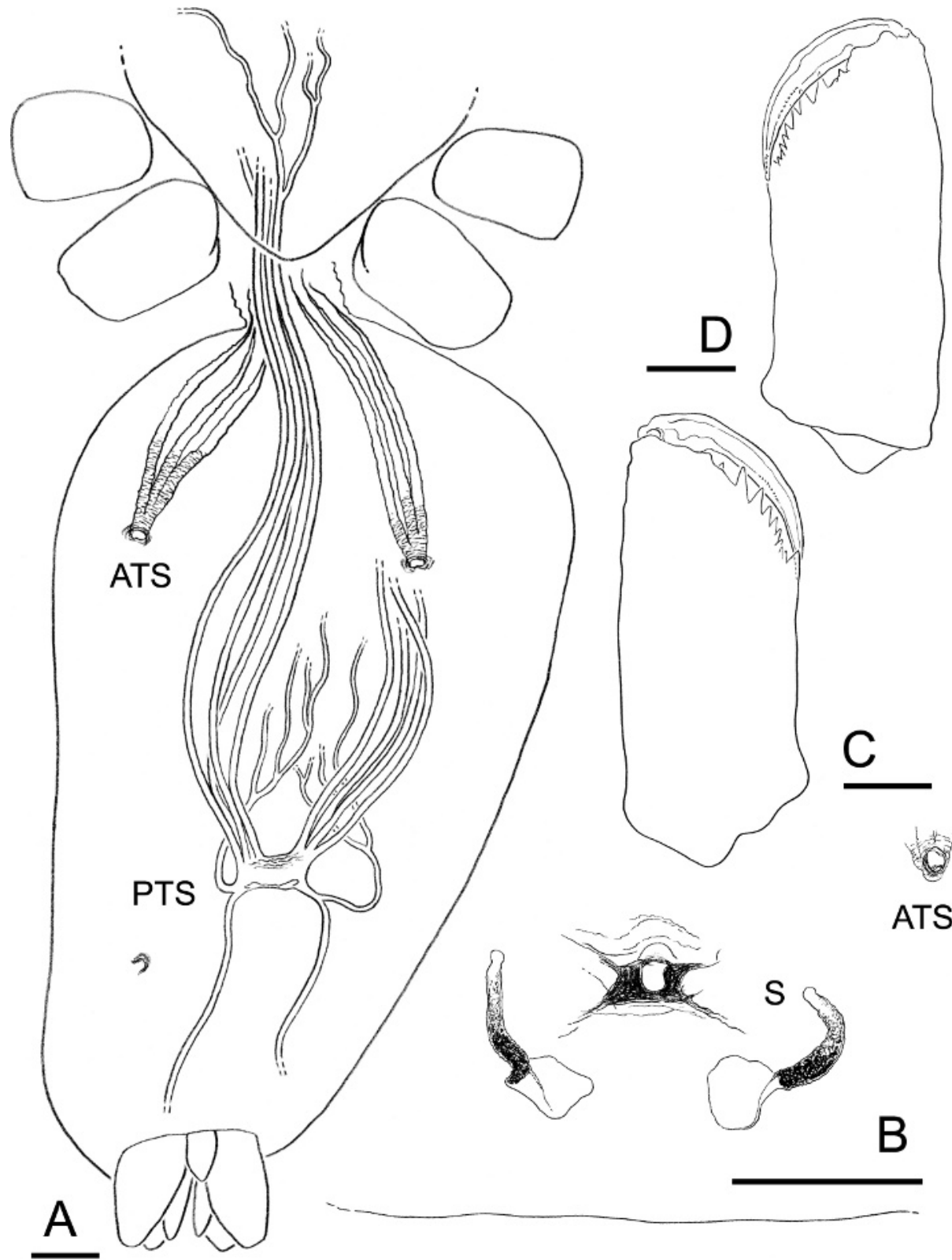

Fig. 3. Ochyrocera cachote, n.sp., female. A, Tracheal system, ventral. B, Genital area. C, Chelicera, dorsal. D, Chelicera, ventral. Scale bars $0.1 \mathrm{~mm}$.

nent single promarginal tooth flanked distally by two small teeth and basally by six small teeth (figs. 1A, B, 2C, D, 4E). Palp (figs. 1A, $\mathrm{B}, 8 \mathrm{~A}-\mathrm{H}$ ): tibia long and cylindrical (ca. 3.6 times its diameter), with two dorsal, two mesal, two ectal trichobothria; cymbium conical, 0.66 the palpal tibia length, with long ectal digitiform apophysis carrying a cuspule at its apical end; tegulum ovoid, tapering to pointed end; sperm duct diameter tapering from reniform fundus (located at tegulum cymbium joint) toward opening, with one 

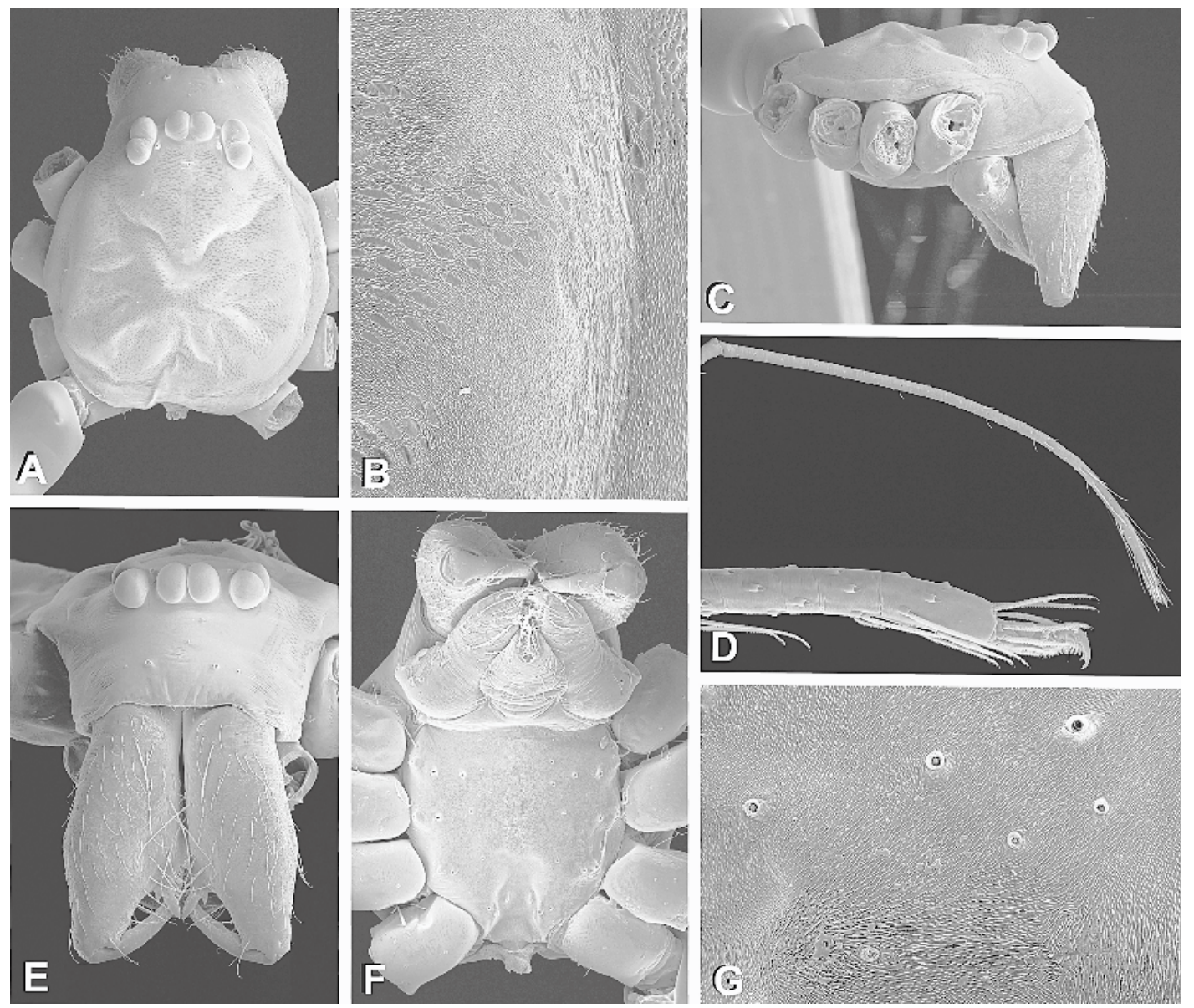

Fig. 4. Ochyrocera cachote, n.sp., male. A, Prosoma, dorsal. B, Prosoma, detail of cuticular surface. C, Prosoma, lateral. D, Leg I, ectal. E, Prosoma, anterior. F, Prosoma, ventral. G, Prosoma, ventral, detail of cuticular surface.

switchback loop; embolus ribbonlike, tapering toward the end and oriented perpendicularly to longitudinal axis of tegulum. Tarsal organ fusiform, apical region divided into three points (fig. 4G). Epiandrous fusules: (fig. 9F) six fusules with globular base linearly arranged in anterior margin of circular depression anterior to epigastric furrow. Spinnerets (fig. 9A-E): colulus fleshy and long (fig. 9A); ALS with one major ampullate gland spigot accompanied by nubbin and seven piriform spigots (fig. 9C); PMS with a single spigot, probably a minor ampullate (fig. 9D); PLS has tightly packed row of 26 aciniform gland spigots with very long bases (fig. 9B, E).
Female (paratype): Total length 2.45. Cephalothorax 0.81 long, 0.7 wide. Sternum 0.43 long, 0.48 wide. Abdomen 1.64 long, 0.81 wide. Coloration and markings as in male, although females seem slightly darker than males (fig. 1C-E). Six eyes in three groups; slightly elevated, with black rings. AME diameter 0.06, 0.3 times one AME diameter away from ALE. Clypeus height 0.22, projecting forward, with two pairs of setae, ectal pair longer and more robust than distal pair (fig. 5A-C). Sternum coloration as in male, labial anterior margin notched (fig. 5F). Pedipalpal tarsal claw a small conical structure (fig. 5I). Legs yellowish with black blotches, no apparent pattern. Pseudoseg- 



Fig. 5. Ochyrocera cachote, n.sp., female. A, Prosoma, dorsal. B, Prosoma, anterior. C, Prosoma, lateral. D, Prosoma, detail of cuticular surface. E, Prosoma, ventral. F, Endites and labium (arrow, labial incision). G, Sternum, detail and cuticular sockets of macrosetae. H, Pedipalp. I, Pedipalpal claw.

mentation present but less apparent than in males. Leg formula 1423. Femur I 2.03 long, 2.5 times length of cephalothorax. Chelicerae with eight small teeth (fig. 3C, D). Vulva (fig. 3B) provided with pair of elongated spermathecae, lightly sclerotized; sclerotized structure of uncertain nature seen between the spermathecae. Spinnerets (fig. 10A-F): colu- 

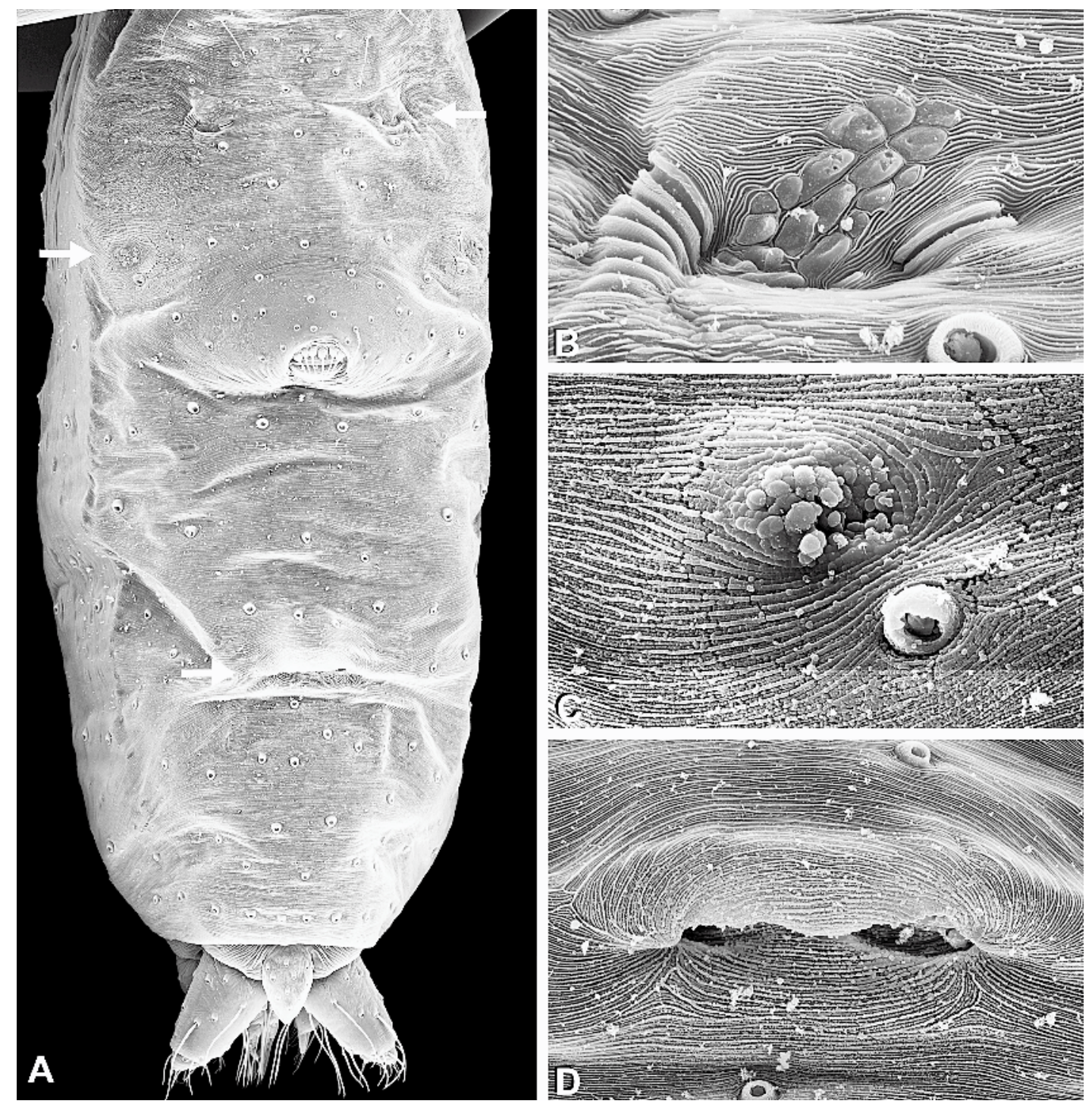

Fig. 6. Ochyrocera cachote, n.sp., male. A, Abdomen, ventral (arrows, from top to bottom, anterior tracheal spiracle, unidentified cuticular structure, and posterior tracheal spiracle). B, Unidentified cuticular structure. D, Detail of cuticular surface and setal socket. D, Posterior tracheal spiracle.

lus, fleshy and long (fig. 7A); ALS with one major ampullate gland spigot accompanied by nubbin and seven piriform spigots (fig. 10E); PMS with single spigot, probably minor ampullate (fig. 10C); PLS has tightly packed row of 23 aciniform gland spigots with very long bases (fig. 10A, B, D, F).

Tracheal system (figs. 3A, 7A, D, 11A-C, $12 \mathrm{~A}-\mathrm{D}$; description is based on single male and female specimen dissection due to paucity of study material): booklungs modified into tracheae that open through anterior spiracles. In male, anterior tracheal system consists of two bundles of three short tracheae confined to abdomen plus leaflike trachea of about half length of other three tracheae (fig. 11A-C). Female anterior tracheal system very similar but lacks leaflike tracheae (fig. 3A). Posterior tracheal system consists of pair of tracheal bundles that open to small atrium (figs. 3A, 



Fig. 7. Ochyrocera cachote, n.sp. A, Female, abdomen, lateral (top arrow, pit; bottom arrow, posterior tracheal spiracle). B, Male, abdomen, lateral. C, Detail of female abdominal pit. D, Female, posterior tracheal spiracle. E, Female, spinnerets, lateral. F, Male, spinnerets, lateral.

$11 \mathrm{~A}-\mathrm{C}, 12 \mathrm{~A}-\mathrm{D})$. Each bundle has four anteriorly directed tracheae that enter prosoma. In the male at least some of those tracheae divide into smaller tracheoles. Female specimen had tracheae broken off in area near pedicel (fig. 11A); their diameter suggests that these tracheae continue into prosoma through pedicel. In female, one of four tracheae of each anteriorly directed bundle branches into smaller tracheoles (fig. 12C). In addition, each bundle has a pair of smaller tracheae (both in diameter and length) that branches into multiple tracheoles. Posterior tracheal spiracle positioned approximately halfway between colulus and epigastric furrow (fig. 10A).

Natural History: Ochyrocera cachote, n.sp. was collected in the leaf litter and in small cavities in the ground in Dominican cloud forests at ca. 940-1200 m of elevation. 

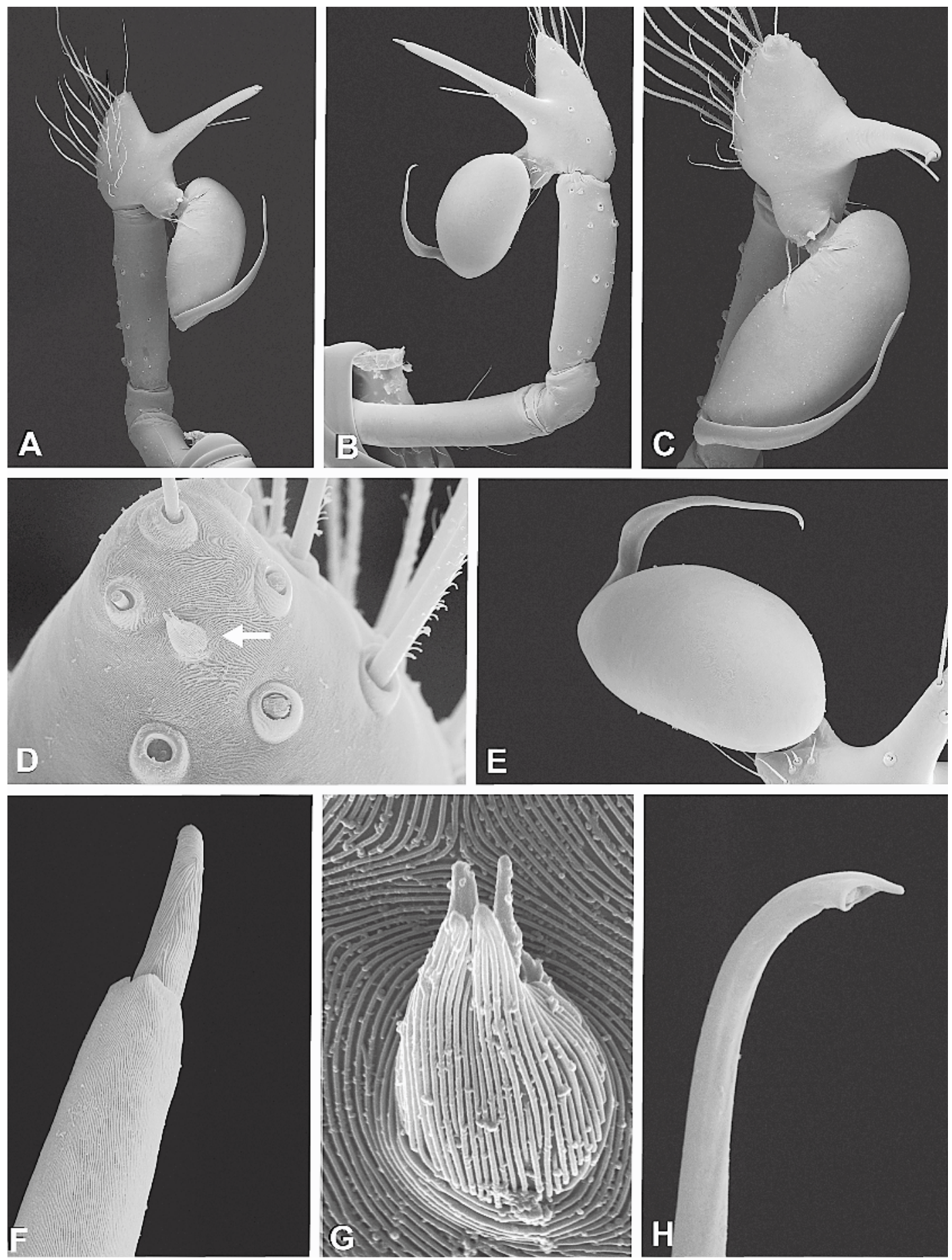

Fig. 8. Ochyrocera cachote, n.sp., male palp. A, Mesoventral. B, Ectal. C, ventral. D, Cymbium, apical (arrow, tarsal organ). E, Tegulum and embolus, ectal. F, Cymbial process and cuspule. G, Tarsal organ. H, Embolus, apical region. 

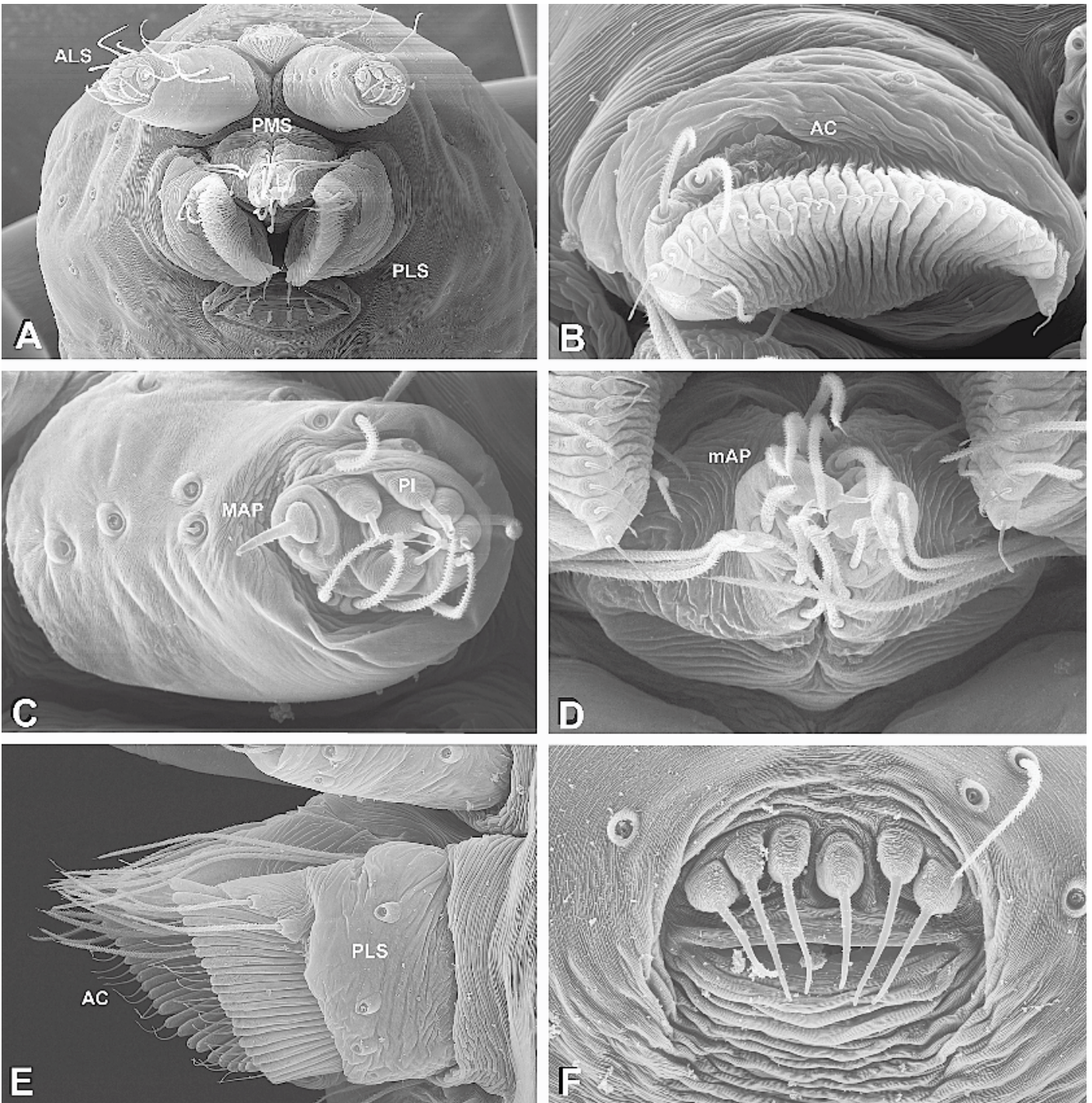

Fig. 9. Ochyrocera cachote, n.sp., male spinning organs. A, Spinnerets and colulus. B, PLS. C, ALS. D, PMS. E, PLS, lateral. F, Epiandrous fusules.

They build small and rather flimsy threedimensional sheet webs with silk lines extending above the sheet (figs. $13 \mathrm{~A}-\mathrm{C}, 14 \mathrm{~A}-\mathrm{C}$ ). The sheet appears to be of structural lines overlaid with finer silk lines running parallel to each other, probably made of silk from the linearly arranged brush of PLS aciniform gland spigots (fig. 7A, B, E, F).

Additional Specimens Examined: Dominican Republic: Barahona Province, Paraíso,
Reserva Natural Cachote, cloud forest surrounded by secondary growth, N18 $05^{\prime} 54.8^{\prime \prime}$ : W71 11'22.0", 1220 m, 6-9.IV.2005, G. Hormiga, F. Alvarez-Padilla, and S.P. Benjamin, 4 males, 7 females (MCZ). Duarte Province, San Francisco de Macorís, Reserva Científica Loma Quita Espuela, cloud forest to tower, N19'21'00.6": $\quad \mathrm{W} 70^{\circ} 08^{\prime} 31.0^{\prime \prime}, 942 \mathrm{~m}, \quad$ 1921.IV.2005. F Alvarez-Padilla and S.P. Benjamin, 2 males, 3 females (MCZ). 

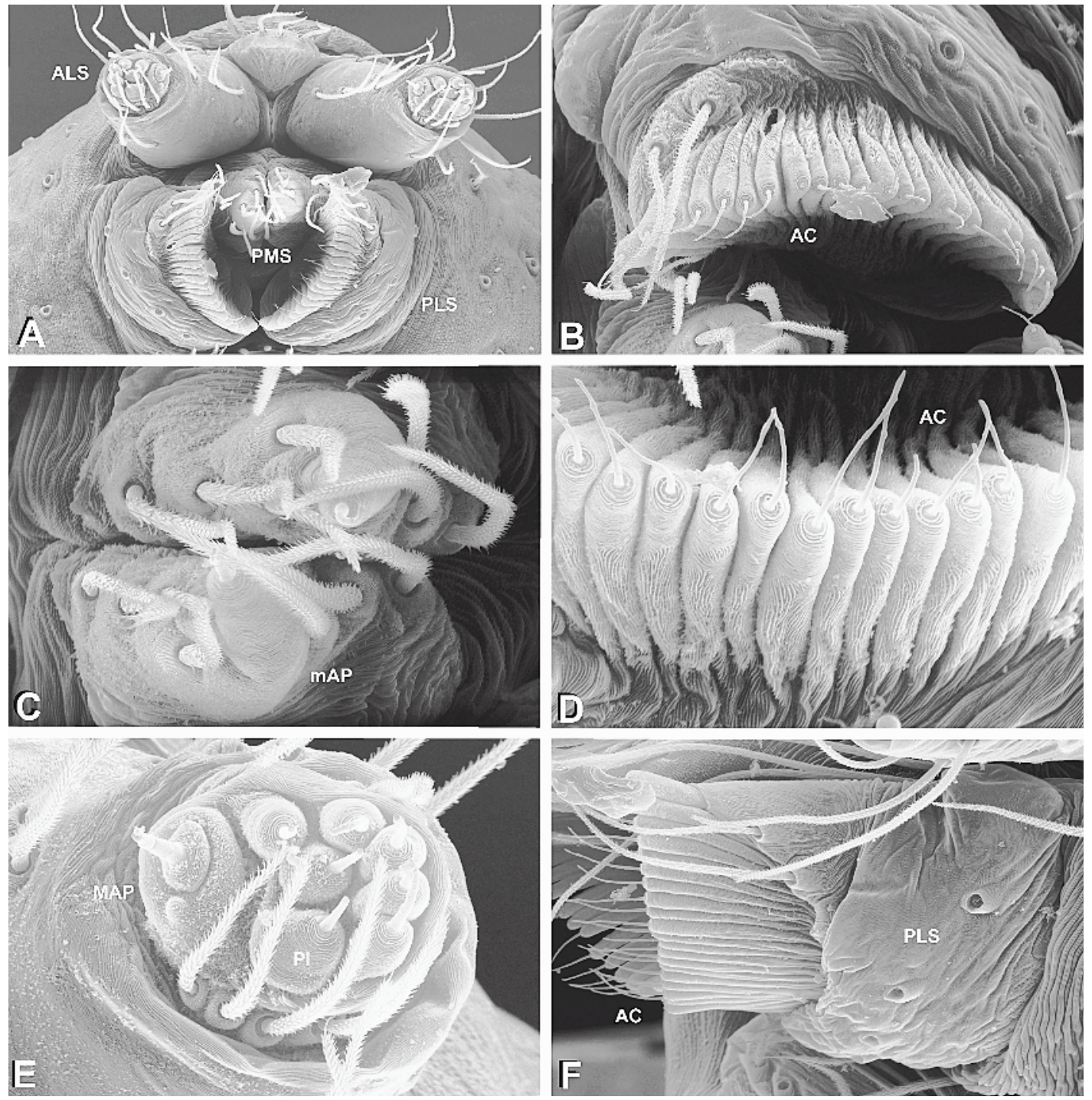

Fig. 10. Ochyrocera cachote, n.sp., Female spinnerets. A, Spinnerets and colulus. B, PLS. C, PMS. D, PLS, detail of aciniform spigots. E, ALS. F, PLS, lateral.

\section{OTHER NEW FAMILY RECORDS FOR HISPANIOLA}

\section{FAMILY MYSMENIDAE}

\section{Microdipoena sp.}

This species was collected in two localities: a sinkhole in the Cueva del Puente (Parque Nacional del Este-Guaraguao) and in a cloud forest in the Duarte Province. Cueva del Puente, in the eastern region of the island, close to sea level (ca. $50 \mathrm{~m}$ of elevation), is located in a coastal area covered with dry forest. The sinkhole area of the cave has shrubby vegetation and higher humidity than does the corresponding epigean area. The spiders built typical "egg-shaped" webs (fig. 15C, D) in crevices among rocks on the ground. In the cloud forest we found Microdipoena sp. webs in the leaf litter. 


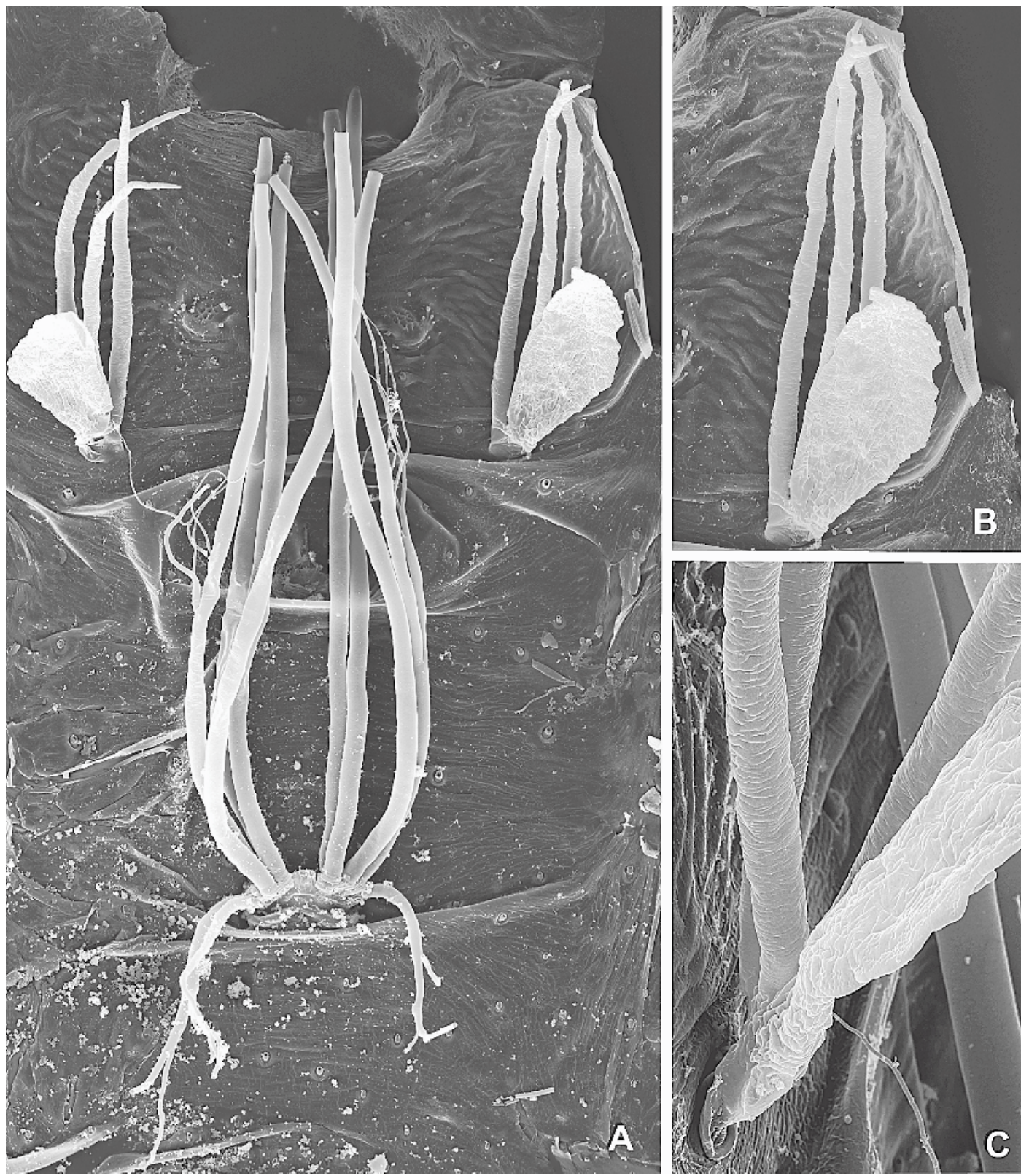

Fig. 11. Ochyrocera cachote n.sp., male tracheal system. A, Ventral. B, Anterior tracheae. C, Detail of anterior tracheae.

Material Examined: Dominican Republic: La Altagracia Province, Guaraguao, Parque Nacional del Este, Cueva del Puente, N18 20'25.4': W 68 48'55.8', 5 m, 2.IV.2005, G. Hormiga, F. Alvarez-Padilla, and S.P.
Benjamin (1 male, 1 female). Duarte Province, San Francisco de Macorís, Reserva Científica Loma Quita Espuela, F. Alvarez-Padilla and S.P. Benjamin, photos 7646-7652 FAP (20.IV.2005, 1 female) (deposited in MCZ). 



Fig. 12. Ochyrocera cachote, n.sp., male tracheal system. A, Base of posterior tracheal trunks. B, Detail of base of posterior tracheal trunk. C, Detail of posterior tracheal trunks and tracheoles. D, Detail of apical region of anterior tracheoles.

\section{FAMILY SYMPHYTOGNATHIDAE}

\section{Patu sp.}

Webs of this species were common in the leaf litter in a cloud forest of the southwestern region of the country (fig. 15A, B). The web was a horizontal planar orb web with numer- ous radii (including many accessory radii) and without out-of-plane radii in the finished webs, as is typical of this family (e.g., Griswold et al., 1998: fig. 3C). The spider is often found upside-down at the hub.

Material Examined: Dominican Republic: Barahona Province, Paraíso, Reserva Natural Cachote, cloud forest surrounded by secondary 
growth, N18 $05^{\prime} 54.8^{\prime \prime}: \mathrm{W} 71^{\circ} 11^{\prime} 22.0^{\prime \prime}, 1220 \mathrm{~m}$, 6-9.IV.2005, G. Hormiga, F. Alvarez-Padilla, and S.P. Benjamin (males and females): photos 9-11/R1 GH (7.IV.2005, 1 female); photos 1215/R3 GH (9.IV.2005, 1 female); photos 16-26/ R3 GH (9.IV.2005, 1 female); photos 7364 7366 FAP (1 female; deposited in MCZ).

\section{Symphytognatha sp.}

Material Examined: Dominican Republic: Barahona Province, Paraíso, Reserva Natural Cachote, cloud forest surrounded by secondary growth, N18 $05^{\prime} 54.8^{\prime \prime}$ : W71 ${ }^{\circ} 11^{\prime} 22.0^{\prime \prime}, 1220 \mathrm{~m}$, 6-9.IV.2005, G. Hormiga, F. Alvarez-Padilla, and S.P. Benjamin (1 female; deposited in $\mathrm{MCZ}$ ).

\section{DISCUSSION}

Ochyroceratids, mysmenids, and symphytognathids are common inhabitants in humid soil microhabitats of the Neotropical region. From a faunistic and taxonomic point of view, the discovery of these three spider families in the Dominican Republic is hardly surprising and, as mentioned above, the presence of the first two families had already been predicted based on the study of Dominican amber. Similarly, we agree with Penney (1999) in predicting that future work will document the presence in the island of the araneoid family Anapidae, so far known only from a fossil species (Palaeoanapis nana Wunderlich, 1988). Brignoli (1983) had suggested that the linyphiid species Lomaita darlingtoni Bryant, 1948, described from Hispaniola, was misplaced and that it could be a mysmenid. Examination of the type material of $L$. darlingtoni (Miller, 2003) and of specimens recently collected by us in the Dominican Republic confirms its correct placement in Linyphiidae.

Our findings confirm Penney's prediction (1999) and highlight the paucity of data on the extant spider fauna of Hispaniola (see Platnick and Penney [2004] and Rheims and Brescovit [2004] for other recent new family records). There has been very little systematic research on the extant spider fauna of the island during the last half-century, which seems rather ironic given the many studies published during the last two decades on the spiders fossilized in Dominican amber.

The systematics of the family Ochyroceratidae remains poorly studied, and generic circumscriptions are often ambiguous. Although the family lacks a global phylogenetic revision, it seems clear that a significant fraction of its diversity remains undescribed. This latter point is well illustrated by Deeleman-Reinhold's (1995) recent taxonomic study of the Indo-Pacific region ochyroceratid fauna: not surprisingly most of the species treated are new. The absence of explicit phylogenetic definitions of ochyroceratid genera considerably complicates the assignment of this new Dominican species to a genus. As mentioned earlier, this new species is morphologically similar to the extinct Dominican species Arachnolithulus longipes and to the extant Ochyrocera thibauldi. It is unclear why Wunderlich (2004a) placed Arachnolithulus longipes in the genus Arachnolithulus, because the male palp morphology of the type species (A. pygmaeus) is rather different from that of A. longipes. The male palps of Fageicera cubana Dumitrescu and Georgescu, 1992 (the type species of Fageicera) and O. cachote, n.sp. are also very similar in having both a long and thin cymbial process with a cuspule at the end (compare fig. 10B to Dumitrescu and Georgescu, 1992: fig. 5). The type species of Ochyrocera (O. arietina Simon, 1891), from Cuba and St. Vincent (Lesser Antilles), also has a cuspule in the apical region of the cymbium. The morphology of the epiandrous fusules of $O$. cachote, n.sp. (fig. 9F) is similar to that reported for other members of the genus, namely $O$. thibauldi (Emerit and Lopez, 1985: fig. 1B) and $O$. caeruleoamethystina Lopez and Lopez, 1997 (Lopez and Lopez, 1997: fig. 27). It consists of six fusules in a circular depression, linearly arranged anterior to the epigastric furrow (there are five in $O$. thibauldi and six in $O$. caeruleoamethysti$n a$ ). It is under these circumstances that we have hypothesized that $O$. cachote, n.sp. is congeneric with the type species of Ochyrocera. Future revisionary and monographic work will test this conjecture.

Very little is known about the natural history and biology of ochyroceratids, and most of what is known about them can be 



Fig. 13. Ochyrocera cachote, n.sp., web architecture (cloud forest in Barahona Province, Paraíso, Reserva Natural Cachote). A, Web in leaf litter. B, C, Details of web showing silk lines running in parallel to each other, probably made of silk from the linearly arranged brush of PLS aciniform gland spigots (all webs dusted with cornstarch). Photos by Gustavo Hormiga. 



Fig. 14. Ochyroceratid webs. A-C, Ochyrocera cachote, n.sp., webs from a cloud forest in Barahona Province, Reserva Natural Cachote. D, Web of an unidentified ochyroceratid from Thailand (Chiang Mai, Doi Inthanon National Park, photo GH36/R02 03.X.2003) showing a similar arrangement of silk lines running in parallel to each other. Photos by Gustavo Hormiga.

found in just a few references, such as the works of Machado (1951, 1964) and Deeleman-Reinhold (1995). The web of $O$. cachote, n.sp. (figs. $13 \mathrm{~A}-\mathrm{C}, 14 \mathrm{~A}-\mathrm{C}$ ) is similar to the webs of other ochyroceratids (Hormiga, unpubl.). A similar architectural pattern of parallel silk lines can be found in other ochyroceratids, such as the species from Thailand that we illustrate for comparative purposes (fig. 14D). Although very little has been published about ochyroceratid web architecture, the presence of linearly arranged 

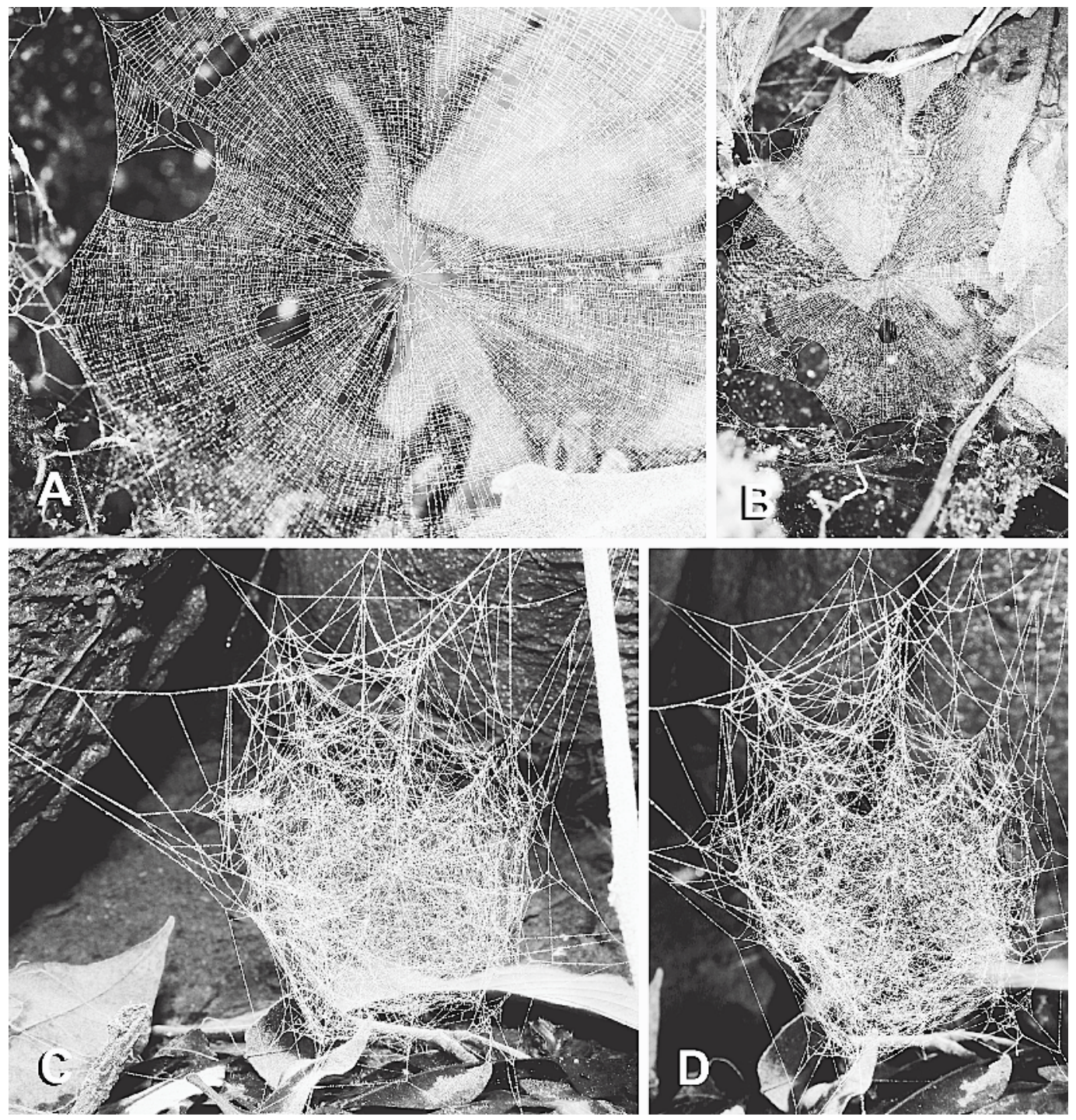

Fig. 15. Webs of Dominican Republic symphytognathids and mysmenids. A, B, Web of Patu sp. (Symphytognathidae), cloud forest in Barahona Province, Paraíso, (Reserva Natural Cachote). C, D, Web of Microdipoena sp. (Mysmenidae), cloud forest in Duarte Province, San Francisco de Macorís (Reserva Científica Loma Quita Espuela). Photos by Gustavo Hormiga (A, B) and Fernando Alvarez-Padilla (C, D).

PLS spigots in other species (e.g., Machado, 1951) predicts that the study of their webs may reveal similarly arranged silk lines running parallel to each other. Such parallel silk lines add a sense of "order" generally not found in non-orb webs.

Web architecture is often informative at some hierarchical level, usually above the species level (Eberhard, 1990). Web architec- ture has been considered to be directly linked to the spider's behavior and not to the arrangement of spinneret spigots (Benjamin and Zschokke, 2003). For example, the highly ordered patterns found in orb webs are considered to be mostly the result of stereotyped web building behaviors (Eberhard, 1982; Benjamin and Zschokke, 2004). Spiders with very similar spinneret spigot morphology 
can build conspicuously different webs. Although we do not have data on the webbuilding behavior of $O$. cachote, the pattern of silk lines running parallel to each other is consistent with the conjecture that it has been produced by the PLS with its linearly arranged spigots. This is the first reported case where apparent order or pattern in the web architecture seems to be generated by the arrangement of spinneret spigots instead of the spider behavior.

\section{ACKNOWLEDGMENTS}

We thank Brian D. Farrell (Harvard University) and Kelvin Guerrero (Santo Domingo, Dominican Republic) for help with the logistics of fieldwork in the Dominican Republic. Fieldwork in Cachote and access to field sites near Paraíso were facilitated by the Sociedad Ecológica de Paraíso, Martiano Moreta, and Oklan Guevara. Fieldwork in Loma Quita Espuela was made possible by the Fundación Loma Quita Espuela. Lara Lopardo provided species identifications for the mysmenids and symphytognathids. Norman I. Platnick helped us with some of the difficultto-get references. David Penney provided an extremely helpful and detailed review of a draft of this work. We also thank Dimitar Dimitrov, Lara Lopardo, and an anonymous reviewer for their useful comments on an earlier draft of this manuscript. Funding for this research was provided by grants from the U.S. National Science Foundation (DEB-0328644 to G. Hormiga and G. Giribet, and EAR-0228699 to W. Wheeler, J. Coddington, G. Hormiga, L. Prendini, and P. Sierwald) and by a REF grant from The George Washington University.

\section{REFERENCES}

Alayón-García, G. 2001. Lista preliminar de las arañas (Araneae) de la isla de Navassa. Cocuyo 10: $18-22$.

Alvarez-Padilla, F., and G. Hormiga. In press. A protocol for digesting internal soft tissues and mounting spiders for scanning electron microscopy. Journal of Arachnology.

Benjamin, S.P., and S. Zschokke. 2003. Webs of theridiid spiders: construction, structure and evolution. Biological Journal of the Linnean Society 78: 293-305.
Benjamin, S.P., and S. Zschokke. 2004. Homology, behaviour and spider webs: web construction behaviour of Linyphia hortensis and L. triangularis (Araneae: Linyphiidae) and its evolutionary significance. Journal of Evolutionary Biology 17: 120-130.

Brignoli, P.M. 1983. A catalogue of the Araneae described between 1940 and 1981. Manchester University Press, Oxford Road, 755 pp.

Bryant, E.B. 1943. The salticid spiders of Hispaniola. Bulletin of the Museum of Comparative Zoology 92: 443-522.

Bryant, E.B. 1945. The Argiopidae of Hispaniola. Bulletin of the Museum of Comparative Zoology 95: 357-422.

Bryant, E.B. 1948. The spiders of Hispaniola. Bulletin of the Museum of Comparative Zoology 100: 329-447.

Coddington, J.A. 1983. A temporary slide mount allowing precise manipulation of small structures. In O. Kraus (editor), Taxonomy, biology, and ecology of Araneae and Myriapoda. Verhandlungen des Naturwissenschaftlichen Vereins in Hamburg 26: 291-292.

Deeleman-Reinhold, C.L. 1995. The Ochyroceratidae of the Indo-Pacific region (Araneae). Raffles Bulletin of Zoology (suppl.) 2: 1-103.

Dingerkus, G., and L.D. Uhler. 1977. Enzyme clearing of alcian blue stained whole small vertebrates for demonstration of cartilage. Stain Technology 52: 229-232.

Dumitrescu, M., and M. Georgescu. 1992. Ochyroceratides de Cuba (Araneae). Mémoires de Biospéologie 19: 143-153.

Eberhard, W.G. 1976. Photography of orb webs in the field. Bulletin of the British Arachnological Society 3: 200-204.

Eberhard, W.G. 1982. Behavioral characters for the higher classification of orb-weaving spiders. Evolution 36: 1067-1095.

Eberhard, W.G. 1990. Function and phylogeny of spider webs. Annual Review of Ecology and Systematics 21: 341-372.

Emerit, M., and A. Lopez. 1985. Ochyrocera thibaudi n.sp. et autres Ochyroceratidae des petites Antilles (Araneae). Revue Arachnologique 6: 81-89.

Grandjean, F. 1949. Observation et conservation des très petits arthropodes. Bulletin du Muséum National d'Histoire Naturelle 21: 363-370.

Griswold, C., J. Coddington, G. Hormiga, and N. Scharff. 1998. Phylogeny of the orb web building spiders (Araneomorphae, Orbiculariae). Zoological Journal of the Linnean Society 123: $1-99$.

Holm, A. 1979. A taxonomic study of European and East African species of the genera Pelecopsis and Trichopterna (Araneae, 
Linyphiidae), with descriptions of a new genus and two new species of Pelecopsis from Kenya. Zoologica Scripta 8: 255-278.

Hormiga, G. 1994. A revision and cladistic analysis of the spider family Pimoidae (Araneoidea, Araneae). Smithsonian Contributions to Zoology 549: 1-104.

Hormiga, G. 2000. Higher level phylogenetics of erigonine spiders (Araneae, Linyphiidae, Erigoninae). Smithsonian Contributions to Zoology 609: 1-160.

Hormiga, G. 2002. Orsonwelles, a new genus of giant linyphiid spiders (Araneae) from the Hawaiian islands. Invertebrate Systematics 16: $1-80$.

Lopez, A., and B. Lopez. 1997. Observations sur deux araignées de la Grotte Fourgassié (Guyana Française): Paratropis papilligera Pick. Cambr., 1896 (Mygalomorphae: Paratropididae) et Ochyrocera caeruleoamethystina n.sp. (Araneomorphae: Ochyroceratidae). Mémoires de Biospéologie 24: 32-42.

Machado, A.de.B. 1951. Ochyroceratidae (Araneae) de l'Angola. Publicações Cultuaris do Companhia de Diamantes Angola 8: 1-88.

Machado, A.de.B. 1964. Ochyroceratidae nouveaux d'Afrique (Araneae). Annals of the Natal Museum 16: 215-230.

Miller, J. 2003. Progress in the systematics of erigonine spiders (Araneae, Linyphiidae, Erigoninae). Ph.D. dissertation, The George Washington University: Washington, D.C.

Penney, D. 1999. Hypotheses for the Recent Hispaniolan spider fauna based on the Dominican Republic amber spider fauna. Journal of Arachnology 27: 64-70.

Penney, D. 2000. Miocene spiders in Dominican amber (Oonopidae, Mysmenidae). Paleontology 43: 343-357.

Penney, D. 2006. An annotated systematic catalogue, including synonymies and transfers, of
Miocene Dominican Republic amber spiders described up until 2005. Revista Ibérica de Aracnología 12: 25-52.

Penney, D., and D.E. Pérez-Gelabert. 2002. Comparison of the Recent and Miocene Hispaniolan spider faunas. Revista Ibérica de Aracnología 6: 203-223.

Platnick, N.I. 2006. The world spider catalog, version 7.0. http://research.amnh.org/entomology/ spiders/catalog81-87/index.html

Platnick, N.I., and D. Penney. 2004. A revision of the widespread spider genus Zimiris (Araneae, Prodidomidae). American Museum Novitates 3450: 1-12.

Rheims, C.A., and A.D. Brescovit. 2004. Revision and cladistic analysis of the spider family Hersiliidae (Arachnida, Araneae) with emphasis on Neotropical and Nearctic species. Insect Systematics and Evolution 35: 189-239.

Schawaller, W. 1981. Survey of the spider families in Dominican amber and other Tertiary resins (Amber Collection Stuttgart: Arachnidae, Araneae). Stuttgarter Beitrage zur Naturkunde (B), 77: 1-10.

Wunderlich, J. 1988. Die Fossilen Spinnen im Dominikanischen Bernstein. Beiträge zur Araneologie 2: 1-378.

Wunderlich, J. 2004a. Fossil spiders (Araneae) of the superfamily Dysderoidea in Baltic and Dominican amber, with revised family diagnoses. Beiträge zur Araneologie 3: 633-74.

Wunderlich, J. 2004b. The fossil spiders of the family Anapidae S. L. (Araneae) in Baltic and Mexican amber and their extant relatives, with the description of the new subfamily Comarominae. Beiträge zur Araneologie 3: 1020-1111.

Wunderlich, J. 2004c. Fossil spiders in amber and copal. Conclusions, revisions, new taxa and family diagnoses of fossils and extant taxa. Part I: Introduction, general findings and conclusions. Beiträge zur Araneologie 3: 9-329. 


Complete lists of all issues of the Novitates and the Bulletin are available at World Wide Web site http://library.amnh.org/pubs. Inquire about ordering printed copies via e-mail from scipubs@amnh.org or via standard mail from: American Museum of Natural History, Library-Scientific Publications, Central Park West at 79th St., New York, NY 10024. TEL: (212) 769-5545. FAX: (212) 769-5009.

అTis paper meets the requirements of ANSI/NISO Z39.48-1992 (Permanence of Paper). 